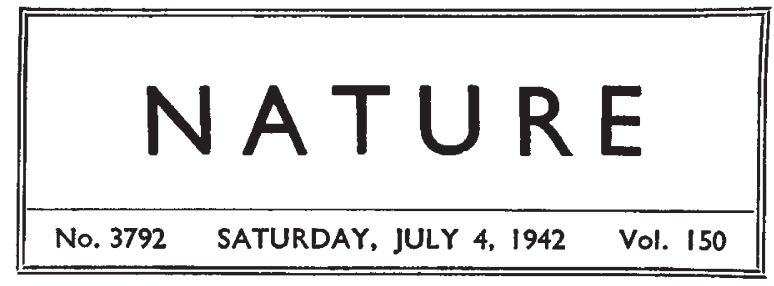

CONTENTS

Sociological Aspects of Production Committees Crater Lake. By Dr. E. B. Bailey, F.R.S. . . The History of Science. By Prof. A. D. Ritchie . Application of Science to Human Needs. By Prof. Willis Jackson

World Affairs. By F. S. Marvin . . . The 'Cellulose Age'. By Dr. Julius Grant . . Morale. By Joseph Geoghegan

Wild Life in the Western Highlands. By Seton Gordon, C.B.E.

What the Plant does with its Materials. By Dr. Hugh Nicol

Ad Astra. By the Right Hon. Lord Brabazon, P.C. News and Views

Letters to the Editors:

Metabolic Water and Desiccation.--Dr. Kenneth Mellanby

Biology of Young Saimon (S. salar, Linn.).--Prof. J. H. Orton

A New Synthetic Fstrogen with Prolonged Action when given Orally.-Dr. J. M. Robson and A. Schönberg

Effect of Extracts of Heterologous Adult Tissue on Cell Growth in vitro and their Use in Wound Healing.-Prof. L. Doljanski, R. S. Hoffman and $E$. Tenenbaum

Human Activities and Soil Characteristics.-Kenneth $L$. Robinson .

A New Synthesis of X-Ray Data for Crystal Analysis.-Dr. H. Lipson . . . .

A Relativity Query.-Dr. R. A. Houstoun . 25

Geologists in War-time.-Dr. Bernard H. Knight Research Items

Recent Archæological Research in Transcaucasia. By

Prof. Ellis H. Minns, F.B.A. . . .

Plankton of Irish Loughs . . . . . 28

'Bog-Butter' from Skye. By M. C. Burkitt . . 29

Mellon Institute of Industrial Research . . . 29

Heat Energy from Radio-active Sources in the Earth 30

Behaviour of Sulphur in Rubber . . . . 31

Electrical Engineering in the United States . . 31

Electromagnetic Waves in Metal Tubes of Rectangular Cross-section

Editorial and Publishing Offices

MACMILLAN \& CO., LTD.,

ST. MARTIN'S STREET, LONDON, W.C.2.

Telephone Number: Whitehall 8831

Telegrams: Phusis Lesquare London

Advertisements should be addressed to

T. G. Scott \& Son, Ltd., Three Gables, London Road, Merstham, Surrey Telephone: Merstham 316

The annual subseription rate is $£ 4100$, payable in advance, Inland or Abroad All rights reserved. Registered as a Newspaper at the General Post Office

\section{SOCIOLOGICAL ASPECTS OF PRODUCTION COMMITTEES}

$7 \mathrm{HE}$ critical importance of establishing effective relations between management and workers in relation to production has been noted in more than one report of the Select Committee on National Expenditure, and one of the main objects of the Joint Production Advisory Committees now being set up is to assist in such integration and to eliminate the misunderstandings which arise when, for example, workers are unaware of the real causes of idle time and other interruptions in production. This factor, it should be noted, is increasingly liable to operate as the mobilization of our industrial man-power and woman-power approaches its limits. There is less and less margin to prevent an interruption at one point causing delays and even more serious interruptions elsewhere.

The value of such attempts to give the workers a true picture of the situation has been well illustrated in a recent visit of a deputation from a local trades and labour council to an ordnance factory, which was reported in the House of Commons. The deputation had full liberty to talk to any employee or shop steward, and the conversations described in the report show how unfounded most of the complaints of idle hours, idle machines and lack of sympathy between management and workers proved to be, and how high an opinion the deputation formed of the per. sonnel and welfare management of the factory compared with private industry. Sir Frederick West, chairman of the North-Western Regional Board of the Ministry of Production, commenting on unfair and inaccurate statements in the report of the Amalgamated Engineering Union on war production with reference to management, confirmed that the Regional Board's own experience in dealing with allegations and rumours criticizing management had indicated that they were mostly unfounded or grossly exaggerated. More substantial grounds of criticism, it is true, are revealed in the investigations of complaints regarding two royal ordnance factories described in the Ninth Report of the Select Committee on National Expenditure, but even here the report shows that the troubles were very largely those which are invariably experienced in starting a factory with an excessive proportion of untrained workers. The superintendents of both factories were fully alive to the problems which confronted them and were doing their utmost to overcome difficulties. Many of the allegations were considerably exaggerated and on most of the matters action had already been taken, though the Select Committee's recommendations, particularly in regard to supervision, the co-ordination of inspection and production, the keeping of records, the handling of transport diffculties and the abolition of Sunday work have a much wider pertinence than in the two factories investigated.

The value of the Joint Production Committees as a weapon of democracy, enabling workers and employers to collaborate in one common and urgent 
drive, receives powerful support in a recent broad. sheөt of Political and Economic Planning (P E P). The workers, accepting the responsibility of full participation in the war effort, are beginning to think in terms of 'we' instead of 'they', and are proving that as efficient collaborators they can be far more than mere mechanical factors of production. By enlisting the intelligence and experience of the men who work with their hands, these Committees enable us to make fuller use of the man-power of Great Britain, and they should in this way do something to meet that shortage of efficient and experienced managers which in places so seriously handicaps our war effort.

If at the same time the fresh brains give an impetus to co-operation and improve the efficiency of production, the Committees will prove themselves unmistakably weapons of war, with the advantage that they could equally prove weapons for winning the peace. The importance of the Production Committees should not in fact be judged only by the extent to which they improve the organization of production. They should be judged also by the changes they effect in the attitude of workers and managements to each other in production relations. It is probable that the Committees will strengthen rather than undermine the trade union movement; they may also lead to a more open mind and a wider outlook on industrial and social affairs on the part of organized labour. This should facilitate the handling of some of the problems of post-war reconstruction as much as it will immediately further the contribution of the workers of Britain in the worldwide struggle for democracy.

The Joint Production Committees are an essentially new development, the strength and significance of which cannot yet be adequately judged, and there are still many obstacles in the way of their success. Some managers oppose them as a superfluous addition to an already widely ramified administrative system. Some trade unionists, on the other hand, are resisting the new Committees on the ground that they are instruments of that industrial collaboration which they have always fought.

Political and Economic Planning has therefore rendered a national service in bringing out so promptly a broadsheet which outlines the facts and sets this new development in its true perspective against the Whitley reports and the experience of works committees and councils, as well as sketching the growth of Production Committees up to their official recognition in February 1942. Success or failure of individual committees will undoubtedly depend largely on the personality of the chairman. He must be capable of bringing out the best in the members, encouraging them to speak frankly, and inspiring open-mindedness, independence and energy. Trade unionists, however, have also a great responsibility for the success of the Committees, and they should not fail to realize the important part which the Committees may play in promoting efficiency. Moreover, this development is so clearly in line with movements in the industrial life of our allies, the United States of America and the U.S.S.R., that it may be of great significance in furthering co-operation with these great countries after the War in the task of restoring order and hope and a new standard of living to the shattered world.

While the main purpose of these developments is to promote the efficiency of our war effort, they have a long-term objective which should not be overlooked. We cannot hope to build a new and more equable social order after the War without mutual confidence and trust between management and workers. The standard of industrial relations which best serves the nation's immediate purpose in war is exactly that which best promotes social justice and order in times of peace. There could be no better illustration of this than the coal industry, in which the attitude of both workers and employers has often been a serious threat to the war effort. What is no less apparent to every impartial observer is the high price which the nation has had to pay for such intransigence and sectionalism in the past. The repercussions on our social economy as a whole in the past twenty or thirty years make the coal industry the very first place where the Government should be required to prove that private and sectional interests shall no longer be allowed to obstruct the national purpose.

The highly suggestive report on "Fatigue of Workers: its Relation to Industrial Production" which was published last year in the United States by the Committee on Work in Industry of the National Research Council, is of particular interest in this connexion. It is no disparagement of the scientific or technical work on the elimination of fatigue, the improvement of conditions of work and prevention of accidents, to emphasize, as this report does, that such physical conditions may be of secondary importance compared with the psycho. logical or social conditions. Neglect of the latter has undoubtedly been a main factor in the persistence of such unhappy conditions in the coal industry.

The National Research Council's report is in the tradition of that line of fundamental research on which Dr. Elton Mayo lays such stress in his stimulating volume "Human Problems of an Industrial Civilisation", and it includes some account of those researches at the Western Electric Co. at Hawthorne which are described in that book as well as in $\mathbf{T} . \mathbf{N}$. Whitehead's "The Industrial Worker" and elsewhere. This section of the book, together with the chapter which summarizes and discusses Mr. C. I. Barnard's book "The Functions of the Executive", give it a significance far beyond that indicated by its title, and it merits careful study by all those concerned with the improvement of industrial relations, whether from the point of view of war production or of reconstruction after the War.

One of the most striking features of the book is the illustration it gives of the lack of knowledge of each others' minds and purposes on the part of management and worker even in such a progressive firm as the Western Electric Co. The investigators formed the opinion that management really knew very little about what constituted good supervision, or what the employees thought about their conditions of work. This lack of communications is responsible 
for the failure to secure the desired results even when good working conditions have been established. An executive order without the participation of the workers may be, and often is, ineffective.

The report points out that, pre-occupied with the continual study of its methods so as to make them more efficient, and making inaccurate assumptions about the motives and behaviour of employees, management gives a series of orders which are transmitted through a hierarchy of supervisors to those doing the physical work. At that level the action does violence to the workers' sentiments and is felt to be a threat to their informal organization, and restrictive or protective action by the workers results. Because technical organization is geared to rapid change, while social organization cannot change rapidly, the latter tends to protect itself by retarding change.

The question of communication itself, however, is both upwards and downwards. Where it is fully established and the worker understands the changes that are proposed and the purposes to be served, co-operation becomes effective and the difficulties tend to disappear. Where for any reason communication both upwards and downwards is good, satisfaction is high and authority is strong.

It is therefore of the utmost importance for management to ensure that the generalizations on which it must in practice rely are accurate and not weighted too heavily by the logic of efficiency and economics. Equally, it must recognize the way in which authority arises out of the collaboration of the individuals affected. The first responsibility for the establishment of communications is that of management downwards, for failure in that direction is at once the cause of failure in the upward direction from the worker.

The second outstanding point which emerges from this report and the researches at the Western Electric Co. is the demonstration of the significance of informal organization. Such organization always exists in conjunction with formal organization, but the importance of its two functions are only now becoming recognized: to transmit information and understandings which, for one reason or another, cannot be transmitted by the formal communication system, and to allow means for individuals to escape from certain effects of formal organizations which tend to disintegrate the personality. The place of the social group in industry presents indeed a most promising field of investigation, for the autonomous groups of M. Dubreuil's scheme are by no means the only means of eliminating the sense of frustration. or repression of individuality which large-scale mechanized industry, however well directed, is apt to engender.

No one can put down this highly suggestive report without realizing how much we have yet to learn from the formal study of human organization, both in furthering the war effort and in building the peace. What Mr. Barmard has to say about the aspects of executive work which are aimed at securing co-operation are also important. Purpose is indeed the unifying principle of organization, and experience of nearly three years of war endorses all that the report observes on this point. What is required to date is in fact to interpret the nation's purpose and its needs so that they are understood by every citizen upon whom it calls for service. Only such understanding and acceptance can call forth the immense moral as well as physical effort required to carry the United Nations to victory. In Great Britain no less than in the United States, the committee of the National Research Council has made a noteworthy contribution to creative thinking and to social and industrial efficiency which has both short-and longrange significance.

\section{CRATER LAKE}

Crater Lake : The Story of its Origin

By H. Williams. Pp. xxii $+100+10$ plates. (Berkeley, Calif.: University of California Press; London : Cambridge University Press, 1941.) 10s. 6d. net.

WE have good reason to be grateful to both Canada and the United States for their contributions to peace as well as to war. Among their most precious gifts are the national parks of the glorious West, which they have consecrated for all future time to the service of humanity. The larger examples, such as Jasper, Yellowstone and the Grand Canyon, harbour men and bears on terms reminiscent of the Garden of Eden. The park of Crater Lake, Oregon, covering roughly 300 square miles, of which a tenth is submerged, is too small to share in this particular distinction; but the blue of its lake and the gay tints of the surrounding cliffs lead some of its devotees to acclaim it as the most beautiful place in the world. Perhaps these enthusiasts have never visited that other park which contains Lake Louise in Alberta; perhaps they say 'most beautiful' when they really mean 'most fascinating'. Be this as it may, all who have had the privilege of visiting Crater Lake admit its rare loveliness, combined with an intellectual stimulus of quite exceptional quality. It is scarcely possible to stand on the rim of the crater and avoid asking the question: How did it happen ?

Fortunately, the two great countries concerned, each within its own boundaries, in the conduct of the national parks of the West clearly recognize the educational possibilities of these institutions. In the United States, J. C. Merriam, chairman of the appropriate committee of the National Academy of Sciences, has helped and encouraged Howel Williams to produce the booklet under notice, which goes far to satisfy the most inquiring visitor. The booklet is excellent in plan, language and illustration-including two coloured plates by Paul Rockwood-excellent, in fact, in all respects but price.

The booklet is in two parts : the first aims at describing the changing scenes of the past as though recorded by a succession of eye-witnesses; the second at presenting some of the evidence in the form of a discussion between a Park Guide and a group of questioning tourists.

The first part is quite unusual. It adopts in language the technique of the illustrator, who occasions no surprise if he does portray in picture, model or diorama the details of an imagined scene of long ago, where only broad outline has really been established. Thus Howel Williams tells of the growth 